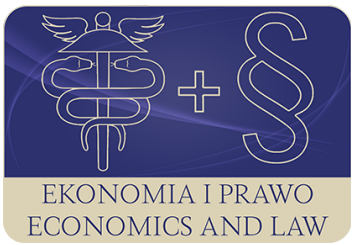

EKONOMIA I PRAWO. ECONOMICS AND LAW

Volume 16, Issue 1, March 2017

p-ISSN 1898-2255, e-ISSN 2392-1625

www.economicsandlaw.pl

ORIGINAL ARTICLE

received 24.09.2015; revised 12.06.2016; accepted 31.03.2017

Citation: Klepczarek, E. (2017). The importance of the board of directors. Lessons from Lehman's

failure. Ekonomia i Prawo. Ecomomics and Law, 16(1): 59-73.

doi:10.12775/EiP.2017.005.

\title{
The importance of the board of directors. Lessons from Lehman's failure
}

\author{
EMILIA KLEPCZAREK \\ University of Lódź, Faculty of Economics and Sociology, Department of Economic Mechanisms, \\ ul. POW 3/5, 90 -255 Eódź, Poland \\ 曰e.klepczarek@uni.lodz.pl
}

\begin{abstract}
Motivation: The effective functioning of the board is usually considered a key factor to minimize conflicts agency. In the literature, the composition of the board, including its size and the fraction of independent members is often pointed out as one of the most important elements determining the effectiveness of its work. The research on the effectiveness of supervision also analyze the activities of board committees, frequency of their meetings, separation of functions Chairman of the Board and CEO and the participation of women. It seems to be an interesting observation that research on the effects of the mentioned factors on the firms performance do not produce clear results. This may lead to a conclusion that one should use some qualitative methods to investigate the corporate governance procedures in the individual entity and work out their possible consequences for the analyzed institution. The case of Lehman Brothers seems to be a good choice for this kind of research as its collapse in 2008 may be found as the evidence for wrong supervision and managing mechanisms. Finding the possible causes of its bankruptcy should give then some guidelines to the proposals of improving the corporate governance systems.

Aim: The purpose of this article is to analyze the conditions under which the board the Lehman Brothers performed supervision and find the cause of irregularities in this area.

Results: The study shows that one cannot unambiguously state that all the board directors were competent, able to commit enough time for controlling and independent.
\end{abstract}

Keywords: corporate governance; Lehman Brothers; risk management; financial crisis JEL: G21; G28; G32; G33; G38 


\section{Introduction}

A declaration of bankruptcy by one of the largest investment banks in the United States was the result of many factors of macro- and microeconomic nature. It is difficult to identify the dominant area of negligence and irregularities that eventually led to the critical situation of the company. However, it seems that the sometimes neglected issue of organizational culture and corporate governance mechanisms played in this case a very important role, contributing significantly to the occurrence of numerous frauds and irregularities. They involved mainly decision-making processes in the field of risk management and risk supervision that were undertaken in conditions of extreme lack of transparent rules, sufficient competence and involvement of the members of the board of directors.

This paper focuses on the issues related to the functioning of the board of directors of Lehman Brothers. The composition of the board, competence of its members, the involvement in the supervisory processes, and the issue of their actual independence will be subject to a detailed analysis. The aim of this paper is to draw attention to the crucial importance of proper understanding and actual implementation of the tasks imposed on the board of directors. The author also tries to find the answer to the question about the causes of improper functioning of this key supervisory authority and to determine whether the causes involved flawed systemic principles, or rather significant weaknesses of their implementation. To resolve these issues is fundamental to develop guidelines for improving the effectiveness of corporate governance in the banking system because it will provide information about the area on which corrective actions should be focused.

The concepts and rules of operation of corporate governance, that from a formal point of view were to be implemented by the members of the board of directors, will be the starting point for the discussion. They have been adopted and approved by the board or set by external supervising institutions. The concepts and rules will be confronted with the realities in which the bank operated in the years before its collapse. This form of analysis will be useful to illustrate a clear dichotomy between the rules formally adopted, and those actually implemented in practice by the bank.

\section{The world research research directions}

The problem of separation of ownership and control already described by Smith (1954) in the 'Wealth of Nations' makes a board of directors the institution playing a key role in the decision-making system of modern organizations. It also seems that the board-related issuesare often analyzed in corporate governance studies. In addition to research relating to the composition of the boards (the share of independent members, the participation of women, the size of the board), researchers consider the level of board activeness, usually measured by the fre- 
quency of meetings, separation of functions Chairman of the Board and CEO and independence of the committees (particularly the audit committee). This latter issue is considered principally important, since the functioning of the board within the committees is considered to be conducive to greater activity and better allocation of responsibilities. It is often investigated whether and how these characteristics affect the performance of enterprises, but there is little research on their correlation with stability or probability of firm bankruptcy.

Table 1 shows the selected characteristics of the boards of directors and their impact on the results that are analyzed in the world literature. On this basis one cannot resolve the probable impact of the participation of independent members and women on the board, as well as the duality of the CEO and chairman function. However, the proportion of independent members in the audit committee seems to be verified as unambiguously positive. It can also be considered that a more active board positively affects performance. The results presented show also no contradiction when concerning the negative correlation of the size of the board and the appointment of risk committee. Nevertheless, although the quantitative results occur unambiguous with some factors (like the board size, existing of the risk committee or the audit committee independence), they seem to be not sufficient to clearly judge their impact in every entity. First of all, there are many methodological pitfalls, which could distort the results of models relating to corporate governance. Börsch-Supan and Koke (2002, pp. 295-326) point to four of these: the reverse causality, missing variables, sample selectivity, and measurement error in variables. Besides, the internal and external environment of each company is so different that the generalization of the importance of particular mechanisms can be very misleading. That is why the case study may be considered as an useful methodology in these kind of analyses.

Despite the significant roles of the boards they are considered today to be one of the weakest corporate governance mechanisms. Jensen (1993, pp. 831880) points several reasons for this situation, emphasizing mainly slowness of reaction (especially when the dismiss of CEO is being concerned), a kind of 'board culture' where the politeness is more important than honesty and integrity, information and communication problems as well as legislative issues that discourage risk taking instead of motivate to action. He also mentions a number of reasons for the inefficiency of boards, such as the lack of participation of members in the company ownership, excessive size and the lack of key investors representation in the board. The existence of these phenomena, as well as frequently observed shortage of competence and commitment of board members, make them acting inefficiently, mindlessly endorsing the management decisions, thereby having a marginal impact on the situation of the supervised company. 


\section{The methodology of research}

This article is a typical case study. As it was mentioned it is useful to analyze particular entity when corporate governance mechanisms are considered. The qualitative research may show some intricacies that are unobserved in general consolidated data. When analyzing governance system this methodology allows to investigate the objectives, assumptions, motives and actions taken by the directors, managers and other corporate stakeholders. As a detailed analysis of the person or the group of people, the case study can be used to indicate the reasons for the person/group or the company he or she managed or supervised has been successful or losing. In other words - case study allows to learn from others' mistakes and that is why the case of Lehman Brothers could be a good one to draw the conclusions.

The analysis will be based on the data regarding the board of directors of Lehman Brothers, whose collapse became a symbol of the financial crisis of 2007-2010. It can therefore be considered as a kind of natural experiment the bankruptcy of this financial holding confirms that it was poorly supervised and poorly managed. The author will try to identify those areas of the board of directors, which could contribute to the problems.

The paper is organized as follows: there will be presented the requirements of international supervisors and/or declarations of Lehman Brothers regarding the board functioning. They will be compared with their actual implementation in the bank in period preceding its bankruptcy. On the basis of this kind of comparison onecan notice how poor was the bank implementation of the recommended or declared standards. There may be even an impression that the Lehman Brothers' board was more a decorative element than the real decision-making body.

\section{Board standards implementation - Lehman Brothers case study}

\subsection{Composition and responsibilities of the board of directors}

In their report on the operations of the company the authorities of Lehman Brothers stress that the board of directors, in which ten people sat, was made up only, with the exception of Richard Fuld, of independent members (United States Securities and Exchange Commission, 2007). They formed four committees (Audit Committee, Nominating and Corporate Governance Committee, Finance and Risk Committee, and the Compensation and Benefits Committee), and one of the members of the Audit Committee was a financial expert in accordance with the requirements of the SEC.

It is worth examining the composition of the board of directors at Lehman Brothers and consider if it could make a reliable, expert, and professional as- 
sessment of the company and if it could control its actions. Table 2 presents the composition of the board of directors, the functions carried out by its members, their age and experience.

While analyzing the composition of the board of directors it is worth recalling that the Basel Committee on Banking Supervision (1999, p. 23) entrusts this body with all activities related to the creation of careful lending and investment criteria, as well as the approval, implementation and periodic review of all internal policies, practices and procedures. Committee guidelines emphasize the need for proper evaluation of the actions undertaken in terms of the bank's exposure to various risks. Directors and managers are also responsible for the overall corporate governance practices, in particular for the introduction of appropriate remuneration policy and strong internal control mechanisms to minimize the risk of the bank's operations.

It is clear from the above considerations that the board of directors plays the overriding role as the most important link of corporate governance. The Basel Committee (2006, pp. 6-7) emphasizes that board members should be characterized by the necessary qualifications to carry out their functions, have full understanding of their role in shaping corporate governance and be able to make reliable assessments of the bank's operations. In the commentary to the first principle of the sound functioning of corporate governance, the Committee lists duties of the board which considerably strengthen internal supervision in the financial sector. In reference to this document, directors should understand and properly fulfill the supervisory function,avoid conflicts of interest and controversy related to their activities and commitments to other organizations, devote sufficient time and energy to fulfill their duties,possess expertise and supervise the senior management of the bank by asking them questions (...)

It is worth relating these requirements to the realities of the functioning of the board of Lehman Brothers. It consisted of ten people, of whom nine were retired, four were over 75 years of age, and only two had experience in the financial industry (Williams, 2010, p.189). Each of the directors of the bank sat on average in three other company boards, and some actively ran their own businesses.

Given the above, it cannot be concluded that the requirements of the Basel Committee were met in this case. People involved in the activities of many entities operating in very diverse industries certainly were not able to devote enough time and energy to monitor the company's operations and to expand their knowledge of the transactions undertaken by modern investment banks. Members of the board of directors of Lehman Brothers did not have appropriate knowledge in the field of securitization and complex derivative instruments, which were in the bank's portfolio, therefore, they could not reliably assess the risk undertaken by the entity they supervised. Therefore it is clear that this was not a model concept of corporate governance that was inappropriate - in this case rather the mechanisms of its implementation failed in select- 
ing the composition of the board, which could not fulfill the fiduciary standard imposed on them.

It is obvious that one cannot require all directors to have detailed knowledge of the structure or the way of constructing complex derivatives. The supervision does not require comprehensive technical knowledge in the particular field of business. Director of the investment bank is not required to know how the particular asset is constructed, however, should be fully aware of the risk involved and how the variable environmental conditions may increase this risk. Directors of Lehman Brothers associated derivatives transactions mainly with double-digit growth of the company's profit, seeming not fully realize that significant involvement in derivatives trading combined with high levels of leverage and inadequate equity is burdened with a higher than average risk of loss, and in extreme cases - bankruptcy ${ }^{1}$.

\subsection{The problem of the independence of the members of the board}

Referring again to the content of the annual report of Lehman Brothers and corporate governance principles for this entity contained therein, it is worth examining the question of the independence of directors, provided in the said document. The New York Stock Exchange - NYSE defines an independent director as the person standing 'outside the interests of the company' (not an interested person) as defined in Section 2 (a) (19) of the Act Investment Company Act (1940) (NYSE, 2003). This act defines in detail a person who is in 'a range of interests' - an interested person. According to the said statute, in the case of an investment company, an interested person is, for example, anyone who is an employee of the company or is the family member of one of its employees, anyone who has a relationship with an investment adviser, attorney, or insurer of the company, as well as all persons and persons related to them who in the past six months have been involved in making any transactions related to the instruments in the portfolio of the particular company and its affiliated companies $^{2}$.

Referring to the above principles, we should mention that the independence of directors declared by Lehman Brothers was a controversial matter. It is sufficient to consider the fact that, although since 2002 the members of the board have been forbidden to use internal investment opportunities, the funds related to the transactions concluded before the ban still flowed into the accounts of people who sat on the board. The Report of the Corporate Library, an in-

1 This kind of approach arises, for example, from the 'Registration Document' prepared in 2007 for the purposes of providing the information disclosure on Lehman Brothers Holdings Inc. LBHI required by Directive 2003/71/EC. There are emphasized the double-digit revenue increases (several times), while the risk connected with the derivatives is not clearly highlighted (Lehman Brothers Holding, 2007).

2 The notion 'interested person' comprises many people, the definition depends also on the type of business entity, in relation to which a person is to be 'independent'. 
dependent rating agency evaluating standards of corporate governance, shows significant payments to members of the board of directors, payments which did not result from the remuneration granted to them (Committee on Oversight and Government Reform, 2008, p. 4). These payments are the result of the investment activity of limited partnerships established before 2002 in the form of employee companies trading in securities (employees' securities companies). These companies made it possible to invest in a full range of instruments held in the portfolio of the bank, such as trade credits, real estate, venture capital funds and other assets offered to external investors. It should be noted that the terms of the transactions for directors, employees or consultants of the bank were much more favorable than those applicable to entities outside the bank. Lehman Brothers or its subsidiaries were general partners in limited partnerships established in this way. Table 3 presents income of Lehman Brothers directors and managers resulting from the involvement in this kind of investment entities, as well as the amount of capital not yet reimbursed to individual limited partners.

The Corporate Library report stresses that in addition to the above reported profits of Lehman Brothers directors, derived from activities associated with Lehman Brothers companies, they also received a refund of contributions of capital which amounted to 96.340 USD for Roger Berlind, 81.520 USD for Scott Freidheim (CAO), 397.250 USD for Richard Fuld, 389.400 USD for Joseph Gregory, 75.000 for Henry Kaufman, 86.143 USD for Ian Lowitt (CAO), 125.674 USD for Christopher O'Meara (CFO), 409.737 USD for Thomas Russo (vice-chairman and CLO), 78.140 USD for adult children of John Akers, and 136.580 USD for adult children of John Macomber. The amounts of returned and unreturned contributions to directors illustrate the scale of their capital involvement in the business entities closely linked to the company that employed them, and the amount of profit reflects the benefits of this involvement, which certainly can be considered as a factor undermining the independence of board members.

It is worth repeating that the practice of sitting on the boards of employee companies was prohibited in 2002, which somewhat confirms its negative impact on the mechanisms of corporate governance. However, at Lehman Brothers, only three members of the supervisory board were not involved in this type of investment. In this situation, the statement taken directly from the report of the company for the year 2007; 'The Board of Directors has determined that (...)Mr. Ainslie, Mr. Akers, Mr. Berlind, Mr. Cruikshank, Ms. Evans, Sir Christopher Gent, Mr. Grundhofer, Mr. Hernandez, Dr. Kaufman and Mr. Macomber are independent and have no material relationships with the Firm' (United States Securities and Exchange Commission, 2008) can be regarded as inconsistent with reality.

There are several other elements that argue against a categorical statement that the Board of Directors of Lehman Brothers was fully independent. These issues are less important than the above investment transactions, but they are 
worth paying attention to. For example, in 2007, the son of Roland Hernandez was employed by the bank as an analyst, and was to work in the summer of 2008. In addition, each of the candidates for directors, with the exception of Marsha Evans and Jerry Grundhofer, had a brokerage or investment account owned by them directly or indirectly as a person managing a family limited liability company which was involved in the business of Lehman Brothers. Moreover, Lehman Brothers obtained revenue from transactions with entities in which Christopher Gent, Roland Hernandez, John Macomber, and Marsha Evans (or members of their families) served as non-executive directors.

All the above relations provide evidence of connection between members of the board and the company in which they were to play the role of an independent body supervising the activities of the bank. One can question the relevance of these relations for the quality of supervisory processes and the company's performance. The research in this area varies with indicating the direction of impactof the independent directors and the company's performance. Nevertheless, in case of Lehman Brothers, it seems reasonable to claim that the voice of the board of directors certainly wasnot a model sovereign advisory voice and the oversight exercised was far from the principles formulated both by the Basel Committee and those appearing in the reports prepared by the company.

\section{Conclusion}

The above analysis of selected issues related to the activities of the board of directors of Lehman Brothers confirms the numerous irregularities in this area of the company's operation. The paper summarizes the model and actual supervisory practices, proving far-reaching discrepancy between the formal principles and their actual implementation. It can be seen that neither the sufficient competency, nor committing enough time for control and being independent were fulfilled within the Lehman's board members. For all problems examined by the author a conclusion can be formulated about the ineffectiveness of the functioning of the mechanisms responsible for the effective implementation of the principles of governance. It follows from this observation that the works on the improvement of the governance should focus more on improving the degree of implementation and the precise wording of the regulation than on their overall substance.

The case of Lehman Brothers is a proof of how important is the issue of sufficient competence and involvement of members of boards of directors in the governance of the banking sector entities. It also shows that many regulations are not reflected in the correctness of their implementation. The situation raises the question about the methods for removing frequent irregularities in economic reality. This issue is extremely important when considering financial institutions with a very wide range of stakeholders and generating the so-called domino effect in the case of possible mistakes in managing the company. In light 
of the above arguments, particularly obvious is a high level of confidence in this type of entities which should involve an absolute requirement of appropriate competence and diligence on part of people who supervise operation of these entities. The transparency and integrity of their actions should be ensured, in addition to an effective regulatory system, by effective monitoring exercised by all interested market participants. This however can only occur when all relevant procedures and transactions, including first of all appointments and dismissals of directors, are fully transparent and open. Shareholders must be convinced that they can actually affect the structure and operation of supervisory authorities. Only then it will be possible to eliminate pathological systems of corporate governance, the supervisory function of which is to a large extent actually a fiction, dangerous for the market.

\section{References}

Aebi, V., Sabato, G., \& Schmid, M. (2012). Risk Management, Corporate Governance, and Bank Performance in the Financial Crisis, Journal of Banking \& Finance, 36(12). doi:10.1016/j.jbankfin.2011.10.020.

Agrawal, A., \& Knoeber, C.R. (1996). Firm Performance and Mechanisms to Control Agency Problems between Managers and Shareholders. The Journal of Financial and Quantitative Analysis, 31(3). doi:10.2307/2331397.

Anderson, R.C., Mansi, S.A., \& Reeb, D.M. (2004). Board characteristics, accounting report integrity, and the cost of debt. Journal of Accounting and Economics, 37(3). doi:10.1016/j.jacceco.2004.01.004.

Baliga, R., Moyer, C., \& Rao, R. (1996). CEO duality and firm performance: What's the fuss? Strategic Management Journal, 17(1). doi:10.1002/ (SICI)1097-0266(199601)17:1<41::AID-SMJ784>3.0.CO;2-\%23.

Basel Committee on Banking Supervision. (1999). Core Principles Methodology. Retrieved 11.07.2016 from http://www.bis.org.

Basel Committee on Banking Supervision. (2006). Enhancing corporate governance for banking organizations. Retrieved 11.07.2016 from http://www.bis. org.

Baysinger, D.B., \& Butler, H.N. (1985). Corporate Governance and the Board of Directors: Performance Effects of Changes in Board Composition. Journal of Law, Economics, \& Organization, 1(1).

Bhagat, S., \& Black, B.S. (2000). Board Independence and Long-Term Firm Performance. Columbia Law School, Law \& Economics Research Paper Series, 143.

Block, S. (1999). The role of nonaffiliated outside directors in monitoring the firm and the effect on shareholder wealth. Journal of Financial and Strategic Decisions, 12(1).

Börsch-Supan, A., \& Köke, J. (2002). An Applied Econometricians' View of Empirical Corporate Governance Studies, German Economic Review, 3(3). doi:10.1111/1468-0475.00061. 
Brickley, J.A., Coles, J.L., \& Jarrell, G.A. (1997). Corporate Leadership Structure: On The Separation of the Positions of CEO and Chairman of the Board. Simon School of Business Working Paper, FR 95-02.

Campbell, K., \& Mínguez-Vera, A. (2007). Gender Diversity in the Boardroom and Firm Financial Performance. Journal of Business Ethics, 83(3). doi:10.1007/s10551-007-9630-y.

Chaganti, R.S., Manajan, V., \& Sharma, S. (1985). Corporate Board Size, Composition and Corporate Failures in Retailing Industry. Journal of Management Studies, 22(4). doi:10.1111/j.1467-6486.1985.tb00005.x.

Chan, K. C., \& Li, J. (2008). Audit Committee and Firm Value: Evidence on Outside Top Executives as Expert-Independent Directors. Corporate Governance: An International Review, 16(1). doi:10.1111/j.1467-8683.2008.00662.x.

Collins, G., \& Osei, K.O. (). The impact of corporate board meetings on corporate performance in South Africa. African Review of Economics and Finance, 2(2).

Committee on Oversight and Government Reform. (2008). The causes and effects of the Lehman Brothers bankruptcy. Retrieved 11.07.2016 from https:// www.gpo.gov.

Dahya, J., \& Travlos, N. (2000). Does the one man show pay? Theory and evidence on the dual CEO revisited. European Financial Management, 6(1). doi:10.1111/1468-036x.00113.

Dahya, J., Dimitrov, O., \& McConnell, J.J. (2008). Dominant shareholders, corporate boards, and corporate value: A cross-country analysis. Journal of Financial Economics, 87(1). doi:10.1016/j.jfineco.2006.10.005.

Daily, C.M., \& Dalton, D.R. (1997). Separate, But Not Independent: Board Leadership Structure in Large Corporations. Corporate Governance, 5(3). doi:10.1111/1467-8683.00053.

Dalton, D.R., Daily, C.M., Ellstrand, A.E., \& Johnson, J.L. (1998). Meta-Analytic Reviews of Board Composition, Leadership Structure, and Financial Performance. Strategic Management Journal, 19(3). doi:10.1002/ (sici)1097-0266(199803)19:3\%3C269::aid-smj950\%3E3.3.co;2-b.

Darmadi S. (2011). Board Diversity and Firm Performance: The Indonesian Evidence. Corporate Ownership and Control Journal, 1(9).

Desi, I. (2008). Board Quality and Firm Performance: The Case of Indonesia's Listed Companies (Unpublished masters thesis, Universiti Utara, Malaysia).

Duchin, R., Matsusaka, J.G., \& Ozbas, O. (2010). When are outside directors effective? Journal of Financial Economics, 96(2). doi:10.1016/j. jfineco.2009.12.004.

Francis, B.B., Hasan, I., \& Wu, Q. (2012). Do Corporate Boards Affect Firm Performance? New Evidence from the Financial Crisis. Bank of Finland Research Discussion Paper, 11. doi:10.2139/ssrn.2041194.

Guest, P. (2009). The impact of board size on firm performance: evidence from the UK. The European Journal of Finance, 15(4). doi:10.1080/13518470802466121. 
Investment Company Act of 1940. (1940). Retrieved 04.03.2014 from http:// www.sec.gov.

Jensen, M.C.(1993). The ModernIndustrial Revolution, Exit, and the Failure ofInternal Control Systems. The Journal of Finance, 48(3). doi:10.2307/2329018.

Krivogorsky, V. (2006). Ownership, board structure, and performance in continental Europe. The International Journal of Accounting, 41(2). doi:10.1016/j. intacc.2006.04.002.

Lehman Brothers Holding (2008). Registration Document from 28 August 2008. Retrieved 11.07.2016 from http://www.bafin.de.

Lehman Brothers Holding. (2007). Registration Document from 28 August 2007. Retrieved 11.07.2016 from http://www.bafin.de.

Mínguez-Vera, A., \& Martin, A. (2011). Gender and management on Spanish SMEs: an empirical analysis. The International Journal of Human Resource Management, 22(14). doi:10.1080/09585192.2011.599948.

Nguyen, H., \& Faff, R. (2006). Impact of board size and board diversity on firm value: Australian evidence. Corporate Ownership and Control, 4(2).

NYSE. (2003). Corporate governance rules. Retrieved 03.03.2014 from http:// www.nyse.com.

Pearce, J.A., \& Zahra, S.A. (1992). Board compensation from a strategic contingency perspective. Journal of Management Studies, 29(4). doi:10.1111/j.1467-6486.1992.tb00672.x.

Pi, L., \& Timme, S.G. (1993). Corporate control and bank efficiency. Journal of Banking \& Finance, 17(2-3). doi:10.1016/0378-4266(93)90050-n.

Post, C., \& Byron, K. (2014). Women on Boards and Firm Financial Performance: A Meta-Analysis. Academy of Management Journal, 58(5). doi:10.5465/amj.2013.0319.

Rechner, P.L., \& Dalton D.R. (1986). Board Composition and Shareholder Wealth: An Empirical Assessment. International Journal of Management, 3(2).

Schellenger M.H., Wood D.D., \& Tashakori A. (1989). Board of Director Composition, Shareholder Wealth, and Dividend Policy. Journal of Management, 15(3). doi:10.1177/014920638901500308.

Shrader, C.B., Blackburn, V.B., \& Iles, P. (1997). Women In Management And Firm Financial Performance: An Exploratory Study. Journal of Managerial Issues, 9(3).

Singh, V., Vinnicombe, S., \& Johnson, P. (2001). Women Directors on Top UK Boards. Corporate Governance, 9(3). doi:10.1111/1467-8683.00248.

Smith, A. (1954). Badania nad naturą i przyczynami bogactwa narodów. Warszawa: PWE.

United States Securities and Exchange Commission. (2007). Form 8-K, Current report pursuant to Section 13 or 15(d) of the Securities Exchange Act of 1934, Lehman Brothers Holdings Inc. Retrieved 03.03.2014 from https: / www.sec.gov.

United States Securities and Exchange Commission. (2008). Schedule 14a Proxy Statement Pursuant To Sectionl4(A) Of The Securities Exchange Act Of 1934, Lehman Brothers Holding Inc., Retrieved 03.03.2014 from https: / www.sec.gov. 
Vafeas, N. (1999). Board meeting frequency and firm performance. Journal of Financial Economics, 53(1). doi:10.1016/s0304-405x(99)00018-5.

Williams, M.T. (2010). Uncontrolled risk. The lessons of Lehman Brothers and how systemic risk can still bring down the world financial system. New York: McGraw Hill.

Yang, T., \& Zhao, S. (2014). CEO duality and firm performance: Evidence from an exogenous shock to the competitive environment. Journal of Banking \& Finance, 49. doi:10.1016/j.jbankfin.2014.04.008.

Yermack, D. (1996). Higher market valuation of companies with a small board of directors. Journal of Financial Economics, 40(2). doi:10.1016/0304-405x(95)00844-5.

Zahra S.A., \& Stanton W.W. (1988). The Implications of Board of Directors' Composition for Corporate Strategy and Performance. International Journal of Management, 5(2).

Zemzem, A., \& Kacem, O. (2014). Risk Management, Board Characteristics and Performance in the Tunisian Lending Institutions. International Journal of Finance \& Banking Studies, 3(1), 186. doi:10.20525/ijfbs.v3il.179.

\section{Acknowledgements}

Author contributions: author have given approval to the final version of the article. 


\section{Appendix}

Table 1 .

\section{Selected board characteristics and their impact on firm performance}

\begin{tabular}{|c|c|c|}
\hline Variable & Impact on performance & Authors \\
\hline \multirow{4}{*}{$\begin{array}{l}\text { Independence } \\
\text { of board mem- } \\
\text { bers }\end{array}$} & Positive & $\begin{array}{l}\text { Baysinger \& Butler (1985, pp. 101-124), Schellenger } \\
\text { et al. (1989, pp. 457-467), Pearce \& Zahra (1992, pp. } \\
\text { 4ll-438), Dahya et al. (2005, pp. 73-100), Krivogor- } \\
\text { sky (2006, pp. 176-197) }\end{array}$ \\
\hline & Negative & $\begin{array}{c}\text { Zahra \& Stanton (1988, pp. 229-236), Agrawal \& } \\
\text { Knoeber (1996, pp. 377-397), Yermack (1996, pp. } \\
\text { 185-211), Bhagat \& Black (2000, pp. 1-41) }\end{array}$ \\
\hline & No correlation & $\begin{array}{l}\text { Rechner \& Dalton (1986, pp. 86-92), Chaganti et } \\
\text { al. (1985, pp. 400-417), Dalton et al. (1998, pp. } \\
\text { 269-290), Duchin et al. (2010, pp. 195-214) }\end{array}$ \\
\hline & $\begin{array}{l}\text { The impact direction depends } \\
\text { on the already existing fraction of in- } \\
\text { dependant members and the existence } \\
\text { of institutional investors }\end{array}$ & Block (1999, pp. 1-8) \\
\hline Size of the board & Negative & $\begin{array}{l}\text { Yermack (1996, pp. 185-211), Guest (2009, pp. } \\
\text { 385-404) }\end{array}$ \\
\hline \multirow{2}{*}{$\begin{array}{l}\text { Board activity } \\
\text { (the frequency } \\
\text { of meetings) }\end{array}$} & Positive & $\begin{array}{l}\text { Collins \& Osei (2011, pp. 83-103), Francis et al. } \\
\text { (2012, pp. 1-58) }\end{array}$ \\
\hline & $\begin{array}{l}\text { Negative on Tobin's q, positiveon } \\
\text { the following-year operational profit }\end{array}$ & Vafeas (1999, pp. 113-142) \\
\hline \multirow{3}{*}{ CEO duality } & Positive & $\begin{array}{c}\text { Pi \& Timme (1993, pp. 515-530), Dahya \& Travlos } \\
\text { (2000, pp. 85-98) }\end{array}$ \\
\hline & Negative & $\begin{array}{c}\text { Brickley et al. (1997, pp. 1-46), Yang \& Zhao (2014, } \\
\text { pp. } 534-552)\end{array}$ \\
\hline & No correlation & $\begin{array}{l}\text { Baliga et al. (1996, pp. 41-53), Daily \& Dalton (1997, } \\
\text { pp. 126-136) }\end{array}$ \\
\hline $\begin{array}{l}\text { Independance } \\
\text { of auditcom- } \\
\text { mittee }\end{array}$ & Positive & $\begin{array}{l}\text { Anderson et al. (2003, pp. 315-342), Chan \& Li } \\
\text { (2008, pp. 16-31), Desi (2008) }\end{array}$ \\
\hline $\begin{array}{l}\text { Existence of risk } \\
\text { committee }\end{array}$ & Negative & $\begin{array}{c}\text { Aebi et al. (2012, pp. 3213-3226), Zemzem \& Kacem } \\
\text { (2014, pp. 186-200) }\end{array}$ \\
\hline \multirow{3}{*}{$\begin{array}{l}\text { Participation } \\
\text { of women }\end{array}$} & Negative & $\begin{array}{l}\text { Shrader et al. (1997, pp. 355-372), Darmadi (2011, } \\
\text { pp. 524-539), Mínguez-Vera \& Martin (2011, pp. } \\
\text { 2852-2873) }\end{array}$ \\
\hline & Positive & $\begin{array}{c}\text { Singh et al.(2001, pp. 206-216), Nguyen \& Faff } \\
\text { (2006, pp. 24-32), Campbell \& Mínguez-Vera } \\
\text { (2008, pp. 435-451) }\end{array}$ \\
\hline & $\begin{array}{l}\text { Depends on the performance } \\
\text { indicators }\end{array}$ & Post \& Byron (2014, pp. 1546-1571) \\
\hline
\end{tabular}

\section{Source: Own preparation.}


Table 2.

\section{Composition of the Lehman Brothers' board of directors}

\begin{tabular}{|c|c|c|c|}
\hline Position & Name & Age* & Experience \\
\hline Chairman of the Board, CEO & Richard S. Fuld Jr. & 62 & $\begin{array}{c}\text { Air Force pilot, since } 1969 \text { an employee of Lehman } \\
\text { Brothers }\end{array}$ \\
\hline $\begin{array}{l}\text { Member of the Audit Com- } \\
\text { mittee }\end{array}$ & Michael L. Ainslie & 64 & $\begin{array}{l}\text { A private investor and former CEO Sotheby's } \\
\text { Holdings, a member of the boards of directors } \\
\text { of numerous companies in the U.S. }\end{array}$ \\
\hline $\begin{array}{l}\text { Chairman of the Compensa- } \\
\text { tion and Benefits Commit- } \\
\text { tee, member of the Finance } \\
\text { and Risk Committee }\end{array}$ & John F. Akers & 74 & $\begin{array}{c}\text { Businessman, former CEO of International Busi- } \\
\text { ness Machines Corporation, a member of the Board } \\
\text { of directors of Pepsi, Hallmark, and other com- } \\
\text { panies. }\end{array}$ \\
\hline $\begin{array}{l}\text { Member of the Finance } \\
\text { and Risk Committee } \\
\text { and the Audit Committee }\end{array}$ & Roger S. Berlind & 78 & Theatrical producer \\
\hline $\begin{array}{l}\text { Chairman of Audit Commit- } \\
\text { tee, Member of Nominating } \\
\text { and Corporate Governance } \\
\text { Committee }\end{array}$ & $\begin{array}{l}\text { Thomas H. Cruik- } \\
\text { shank }\end{array}$ & 77 & $\begin{array}{c}\text { Retired CEO of Halliburton Company (an oil-field } \\
\text { services company) }\end{array}$ \\
\hline $\begin{array}{l}\text { Chairwoman of the Nominat- } \\
\text { ing and Corporate Govern- } \\
\text { ance Committee, member } \\
\text { of the Compensation and Ben- } \\
\text { efits Committee and of the Fi- } \\
\text { nance and Risk Committee }\end{array}$ & $\begin{array}{l}\text { Marsha Johnson } \\
\text { Evans }\end{array}$ & 61 & $\begin{array}{l}\text { Retired U.S. Navy Rear Admiral, CEO } \\
\text { of the American Red Cross }\end{array}$ \\
\hline $\begin{array}{l}\text { Member of the Audit Com- } \\
\text { mittee and the Compensation } \\
\text { and Benefits Committee }\end{array}$ & $\begin{array}{l}\text { Sir Christopher } \\
\text { Gent }\end{array}$ & 60 & $\begin{array}{l}\text { British businessman, former CEO of Vodafone, } \\
\text { Non-executive Director at GlaxoSmithKline plc }\end{array}$ \\
\hline $\begin{array}{l}\text { Member of the Finance } \\
\text { and Risk Committee }\end{array}$ & $\begin{array}{l}\text { Roland A. Her- } \\
\text { nandez }\end{array}$ & 50 & $\begin{array}{c}\text { Retired CEO of Telemundo Group, member } \\
\text { of the supervisory boards of MGM Mirage (casi- } \\
\text { nos), Wal-Mart and others }\end{array}$ \\
\hline $\begin{array}{l}\text { Chairman of the Finance } \\
\text { and Risk Committee }\end{array}$ & $\begin{array}{l}\text { Dr. Henry Kau- } \\
\text { fman }\end{array}$ & 81 & $\begin{array}{l}\text { Since 1998, the president of the company he } \\
\text { founded, Henry Kaufman \& Company, Inc. which } \\
\text { specializes in financial advisory, previously director } \\
\text { at Salomon Brothers and economist at FED }\end{array}$ \\
\hline $\begin{array}{l}\text { Member of the Compensa- } \\
\text { tion and Benefits Commit- } \\
\text { tee and of the Nominating } \\
\text { and Corporate Governance } \\
\text { Committee }\end{array}$ & $\begin{array}{l}\text { John D. Ma- } \\
\text { comber }\end{array}$ & 80 & $\begin{array}{l}\text { Head of JDM Investment Group, former chairman } \\
\text { of the Export-Import Bank of the United States } \\
\text { and CEO at Celanese Corporation }\end{array}$ \\
\hline $\begin{array}{l}\text { Member of the Compensation } \\
\text { and Benefits Committee** }\end{array}$ & Dinna Merril & 83 & Actress \\
\hline $\begin{array}{l}\text { Member of the Board of Di- } \\
\text { rectors*** }\end{array}$ & Jerry Grundhofer & 63 & Former CEO and Chairman of U.S. Bancorp \\
\hline
\end{tabular}

* Age given for 2008

** Occupied the position on the board until 2006

*** Appointed director at Lehman Brothers in April 2008

Source: Own preparation. 
Table 3 .

Involvement of directors and managers of Lehman Brothers in the business of limited partnerships investing in the instruments that were in the portfolio of the bank. As at 30 November, 2007 (in USD)

\begin{tabular}{ccc}
\hline Limited Partner & $\begin{array}{c}\text { Distributions of profits in fiscal year } \\
2007\end{array}$ & $\begin{array}{c}\text { Aggregate unreturned limited } \\
\text { partner capital }\end{array}$ \\
\hline Michael L. Ainslie & $*$ & $* *$ \\
Roger S. Berlind & 72.670 & 298.609 \\
Erin M. Callan & $*$ & $* *$ \\
Thomas H. Cruikshank & $*$ & $* *$ \\
Scott J. Freidheim & 64.598 & 499.436 \\
Richard S. Fuld, Jr. & 463.460 & 4.521 .124 \\
Joseph M. Gregory & 419.020 & 4.806 .682 \\
Henry Kaufman & 68.250 & $* *$ \\
Ian T. Lowitt & 89.007 & 1.071 .042 \\
Christopher M. O’Meara & 107.342 & 2.397 .320 \\
Thomas A. Russo & 558.447 & 6.684 .320 \\
Adult children of John F. Akers & 42.280 & $* *$ \\
Adult children of John D. Ma- & 107.390 & 439.489 \\
comber & &
\end{tabular}

* This amount, together with the return of contributions did not exceed 120.000 USD

** The amount did not exceed 120.000 USD

Source: Own preparation based on Lehman Brothers Holding (2008, pp. 59-60). 
